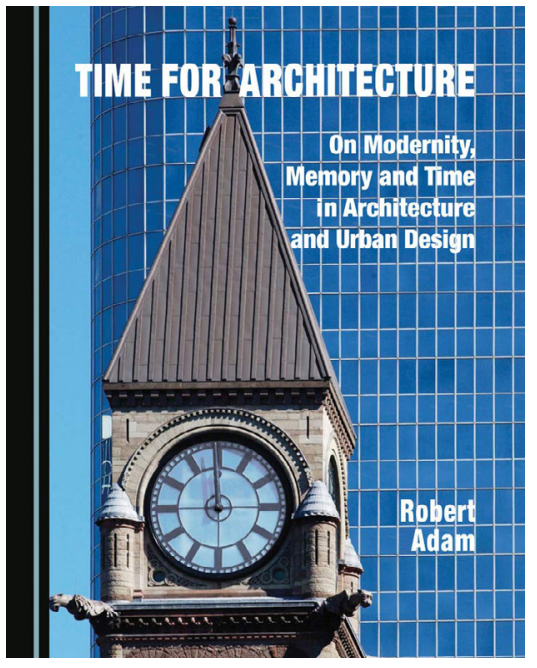

\section{If we look for timelessness in architecture, we must look to tradition}

\section{Si buscamos lo atemporal en la arquitectura, debemos acudir a la the sense of stepping outside time and change that comes from ignoring passing fashions, we must look to tradition rather than Modernism.} tradición

\section{Se procurarmos a intemporalidade na arquitectura, temos de olhar para a tradição}

\section{Clive Aslet}

Earlier this year, around March, time changed. The world stopped. People who had previously been busy travelling to their offices or jetting off to distant destinations found themselves in a state of suspended animation. Confined to their homes, many people found that the days grew longer, because there was little to fill them. They didn't look so much at their watches or mobile phone displays so often. The clock has not yet properly restarted.

So this is a good moment for Robert Adam, an exceptionally thoughtful architect, to bring out his latest volume: Time for Architecture: On Modernity, Memory and Time in Architecture and
Urban Design. Architecture exists in time, because it is slow to build and subject to the normal processes of decay. But a host of critics have adopted 'timeless' as a term of high praise. It doesn't take more than a couple of illustrations of supposedly timeless buildings to realise that they have quickly become dated. No more than a glance is needed to know that Michael Graves's Denver Public Library was built about 1990 .

Architects are no more successful at predicting the future than astrologers or soothsayers. Human beings are quick to adapt to new realities and development does not go in a straight line; they can have - from a Modernist perspective - a perverse attachment to traditions that bring the past into the present. If timelessness means

As Professor Adam makes clear in the first paragraph of this engaging book, our awareness of time is related to the span of human life. This is not simply a meditation on mortality, however. Buildings outlast individuals and the best age gracefully. European cities are full of architecture that is many hundreds of years old. They embody the collective memory that's part of culture. This is a doubly important consideration in an age when certain protest groups are intent on expunging history that they consider unacceptable - by toppling statues, for example because only one version of memory should be allowed to exist. Far more numerous than ancient buildings are ones that aren't expected to last more than 30 years. That is a betrayal of all the labour, energy and carbon that goes into them. Their deliberate lack of permanence is an assault on our perceptions of time itself.

\section{Robert Adam}

Time for Architecture: On Modernity,

Memory and Time in Architecture and

Urban Design

Cambridge Scholars Publishing, 2020

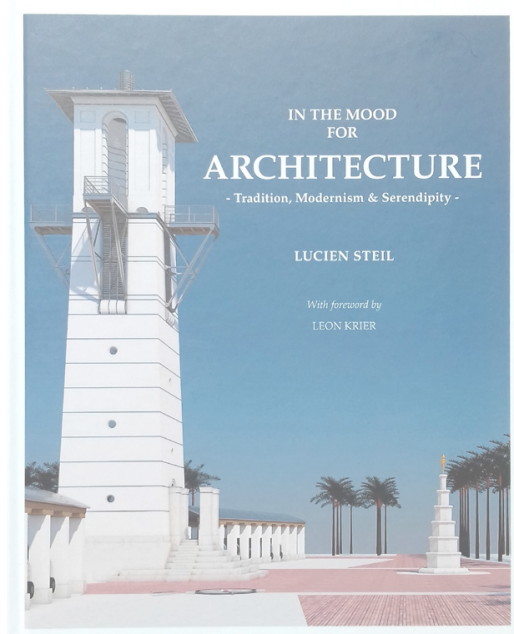

\section{A Prelude to New Ways}

of Thinking about

\section{Traditionalism}

\section{Un preludio a nuevas maneras de concebir el \\ tradicionalismo}

\section{Um preludio para novas \\ formas de pensar sobre o \\ tradicionalismo}

\section{Victoria L. V. Schulz-Daubas}

Lucien Steil's book In the Mood for Architecture, Tradition, Modernism \& Serendipity offers an illuminating and refreshing perspective on contemporary traditional architecture, and what it stands for today. Distilling a wealth of experiences as an architect, artist, teacher and writer, Lucien explores the grounding principles of traditional architecture; principles proven to bring harmony, vitality and variety to the built environment, as the continuing appeal of historic cities testifies. His comparisons between traditional and modern cities sharpen one's own sensibility for the relationship between cultural heritage and local context, between the timetested and the new.

Throughout the book, Lucien's observations shedlight on prejudice and 